\title{
IMPLEMENTASI KOMITMEN PEMBANGUNAN BERKELANJUTAN DALAM KONSTITUSI SEBAGAI WUJUD PEMENUHAN HAK EKONOMI, SOSIAL DAN BUDAYA DI INDONESIA
}

\author{
Cholidah \\ Fakultas Hukum Universitas Muhammadiyah Malang \\ Jalan Raya Tlogomas No. 246, Tlogomas, Lowokwaru, Babatan, Tegalgondo, 65144 \\ E-mail: cholidahbaghos@gmail.com
}

\begin{abstract}
As a concept of sustainable development it is seen to support the development of human rights, especially Ekososb rights where the fulfillment of human rights no longer focuses only on the current generation but also focuses on fulfilling human rights for future generations. This research was conducted with the aim of analyzing and understanding about Indonesia's commitment after signing the International Sustainable Development Goals Commitment in 2015. This research use normative juridical methods that will analyze the concept of sustainable development in Indonesian legislation and the relation of the concept of sustainable development to the fulfillment of human rights for the people of Indonesia. The author believes that basically the concept of sustainable development is a challenging target for Indonesia as a developing country, but the achievement of this target must be sought by making concrete steps in the framework of fulfilling the global commitments that have been made by the world community to realize justice Asasi is not only for people in developed countries but also for the current generation sustainable development commitment is expected to provide fulfillment of cross-generation and cross-Regional Human
\end{abstract}

Key words: Suistainabel Development, Legislation, Human Rights

\begin{abstract}
ABSTRAK
Konsep pembangunan berkelanjutan dipandang mendukung perkembangan HAM terutama hak ekonomi, sosial dan budaya dimana pemenuhan HAM tidak lagi hanya berfokus kepada generasi yang ada saat ini namun juga fokus terhadap generasi yang akan datang. Penelitian ini dilakukan dengan tujuan untuk menganalisis dan memahami tentang komitmen Indonesia pasca melakukan penandatanganan Komitmen tujuan pembangunan berkelanjutan Internasional pada tahun 2015. Penelitian ini mengggunakan metode yuridis normatif dengan menganalisis tentang konsep pembangunan berkelanjutan di dalam perundangan Indonesia serta relasi konsep pembangunan berkelanjutan terhadap pemenuhan HAM bagi rakyat Indonesia. Penulis berpendapat bahwa konsep pembangunan berkelanjutan merupakan target yang cukup menantang untuk dicapai oleh Indonesia sebagai negara yang sedang berkembang yang harus diupayakan dengan melakukan langkah-langkah konkrit dalam rangka pemenuhan komitmen global yang telah di buat oleh masyarakat dunia demi mewujudkan keadilan Asasi tidak hanya bagi masyarakat di negara-negara maju maupun generasi saat ini tetapi juga lintas generasi dan lintas regional.
\end{abstract}

Kata kunci : Pembangunan Berkelanjutan, Perundang-undangan, Hak Asasi Manusia

\section{PENDAHULUAN}

Sustainable Development Goals (SDGs) di sepakati di New York dalam Sidang Umum
PBB sekaligus perayaan ke 70 tahun pembentukan PBB pada 25-27 September 2015 Komitmen SDGs di sepakati bersama 
menggantikan program Millennium

Development Goals (MDGs) yang telah berakhir pada tahun 2015. SDGs tersebut akan otomatis berlaku bagi negara-negara maju dan berkembang untuk 15 tahun ke depan dimulai dari tahun 2015 sampai dengan 2030 Tujuan dari agenda baru PBB tersebut tidak berbeda jauh dari program sebelumnya, yang di antaranya mengakhiri kemiskinan, menjamin kehidupan sehat, mempromosikan pendidikan dan memerangi perubahan iklim.

The Guardian menulis 7 alasan mengapa SDGs akan jauh lebih baik dari MDGs, yakni: ${ }^{1}$

1. SDGs lebih global dalam mengkolaborasikan program-programnya. MDGs sebelumnya dibuat oleh anggota negara OECD dan beberapa lembaga internasional. Sementara SDGs dibuat secara detail dengan negosiasi internasional yang juga terdiri dari negara berpendapatan menengah dan rendah.

2. Sekarang, sektor swasta juga akan memiliki peran yang sama, bahkan lebih besar.

3. MDGs tidak memiliki standar dasar Hak Asasi Manusia (HAM). MDGs dianggap gagal untuk memberikan prioritas keadilan yang merata dalam bentukbentuk diskriminasi dan pelanggaran HAM, yang akhirnya berujung kepada masih banyaknya orang yang terjebak dalam kemiskinan. Sementara SDGs dinilai sudah didukung dengan dasardasar dan prinsip-prinsip HAM yang lebih baik.

4. SDGs adalah program inklusif. Tujuh target SDG sangat eksplisit tertuju kepada orang dengan kecacatan, dan tambahan enam target untuk situasi darurat, ada juga tujuh target bersifat universal dan dua target ditujukan untuk antidiskriminasi.

5. Indikator-indikator yang digunakan memberikan kesempatan untuk keterlibatan masyarakat sipil.

6. PBB dinilai bisa menginspirasi negaranegara di dunia dengan SDGs.

7. COP21 di Paris adalah salah satu kesempatan untuk maju.

Menurut, Wakil Presiden Jusuf Kalla dalam pidatonya dalam konfrensi ini di Markas Besar PBB, New York menyatakan bahwa Millenium Development Goals (MDGs) yang akan berakhir pada 2015 belum berhasil mencapai target. "Ketidaksetaraan dan kemiskinan menjadi masalah global hingga kini. Bahkan sejumlah tantangan baru muncul seperti kesenjangan energi, infrastruktur, pola konsumsi, keterbatasan produksi, dan perubahan iklim. ${ }^{2}$

Melihat dari pernyataan wakil presiden tentang belum tercapainya Millenium

\footnotetext{
1 Tujuh alasan SDGs lebih baik dari MDGs, https://beritagar.id/artikel/berita/tujuh-alasan-sdgs-lebih-baik-darimdgs. Diakses pada tanggal 5 Juni 2019.

2 Ibid.
} 
Development Goals (MDGs) yang lebih sederhana capaianya maka muncul pertanyaan bagaimana dengan SDGs yang lebih komplek termasuk implementasi prinsip - prinsip HAM yang dijadikan landasan Sustainable Development Goals (SDGs) sementara pelaksana lembaga yang diberikan wewenang untuk menjalankan komitmen tersebut adalah Bappenas yang merupakan lembaga teknis perencanaan pembangunan dan belum didukung dengan Keputusan Presiden (Kepres) dalam rangka mengawal SDGs.

Pada dekade 1980-an banyak kelompok studi yang mendiskusikan orientasi pembangunan "Growth" versus "Development" tersebut. Salah satu yang dapat disebutkan di sini adalah "Club of Rome", kelompok yang kemudian mengemukakan argumen tentang "Limit to Growth". Selanjutnya pada dekade 1990-an, PBB membawa isu orientasi pembangunan yang mengarah pada kesejahteraan umat manusia tersebut (development) ke dalam pembahasan, diskusi, serta kesepakatan antarnegara. Tahun 1992, misalnya, diselenggarakan KT Bumi di Rio de Janeiro. Tahun 1994 digelar pula Konferensi Kependudukan dan Pembangunan di Kairo. Tahun 1995, ganti Konferensi Gender dan Pemberdayaan Perempuan dilaksanakan, berikut beberapa konferensi lainnya yang sejalan setelah itu. ${ }^{3}$

Puncak dari upaya mengedepankan pembangunan yang berorientasi pada kesejahteraan umat manusia, baik untuk generasi saat ini maupun generasi mendatang, adalah lahirnya kesepakatan kepala negara dan kepala pemerintahan 189 negara mengenai Deklarasi Milenium. Deklarasi ini berisi kesepakatan negara-negara tentang arah pembangunan berikut sasaran-sasarannya yang perlu diwujudkan. Secara ringkas, arah pembangunan yang disepakati secara global meliputi: ${ }^{4}$

1. Menghapuskan kemiskinan dan kelaparan berat;

2. Mewujudkan pendidikan dasar untuk semua orang;

3. Mempromosikan kesetaraan gender dan pemberdayaan perempuan;

4. Menurunkan kematian anak;

5. Meningkatkan kesehatan maternal;

6. Melawan penyebaran HIV/AIDS, dan penyakit kronis lainnya (malaria dan tuberkulosa);

7. Menjamin keberlangsungan lingkungan;

8. Mengembangkan kemitraan global untuk pembangunan.

Realisasi Target SDGs ke dalam Kebijakan Hukum nasional secara nyata terlihat dari

\footnotetext{
3 Tim Penyusunan Laporan Tujuan Pembangunan Milenium (MDGs) Indonesia Tahun 2007 (Kementerian Negara Perencanaan Pembangunan Nasional/Badan Perencanaan Pembangunan Nasional), (2007), Laporan Pencapaian Millenium Development Goals Indonesia Tahun 2007, Jakarta: Badan Perencanaan Pembangunan Nasional, hlm. 3.

$4 \quad$ Ibid.
} 
peningkatan pembuatan Perundang-undangan yang berkaitan dengan Hak Ekososbud sebagaimana terlihat dalam tabel berikut.

Tabel 1. Tabel pengesahan undang -undang baru tahun 2015, 2016 dan 2017

\section{5}

1. Undang-undang

Nomor 1 tahun 2015 tentang perubahan atas Undang-undang Nomor 30 Tahun 2002 tentang Komisi Pemberantasan

Tindak

Pidana

Korupsi menjadi undang-undang
2016

2017

1. Undang-undang Nomor 1. Undang-undang Nomor 5 13 Tahun 2016 Tentang Paten

Tahun 2017 tentang Pemajuan Kebudayaan

2. Undang-Undang Nomor 15 Tahun 2016 Tentang Pengesahan Maritime Labour Convention 2006

Konvensi

Ketenagakerjaan Maritim 2006

3. Undang-Undang

Nomor 17 Tahun 2016 tentang Penetapan Peraturan Pemerintah Pengganti Undangundang Nomor 1 Tahun 2016 Tentang Perubahan Kedua Atas Undang-undang Nomor 23 Tahun 2002 tentang Perlindungan Anak menjadi undangundang

4. Undang-undang Nomor 16 Tahun 2016 tentang 7 Pengesahan Paris Agreement To The United Nations

Framework Convention On Climate Change (Persetujuan Paris Atas Konvensi Kerangka Kerja Perserikatan Bangsa-Bangsa Mengenai Perubahan Iklim)

5. Undang-undang Nomor 8 Tahun 2016 tentang Penyandang Disabilitas

6. Undang-undang Nomor 19 Tahun 2016 tentang
2. Undang-undang Nomor 9 Tahun 2017 Tentang Penetapan Peraturan Pemerintah Pengganti

3. Undang-undang Nomor 1 Tahun 2017 tentang Akses Informasi Keuangan untuk Kepentingan Perpajakan menjadi undang-undang

. Undang-undang Nomor 11 Tahun 2017 tentang Pengesahan Minamata Convention On Mercury

5. Undang-undang Nomor 2 Tahun 2017 tentang Jasa Konstruksi (Konvensi Minamata Mengenai Merkuri)

6. Undang-undang Nomor 6 Tahun 2017 tentang Arsitek

7. Undang-undang Nomor 7 Tahun 2017 tentang Pemilihan Umum 


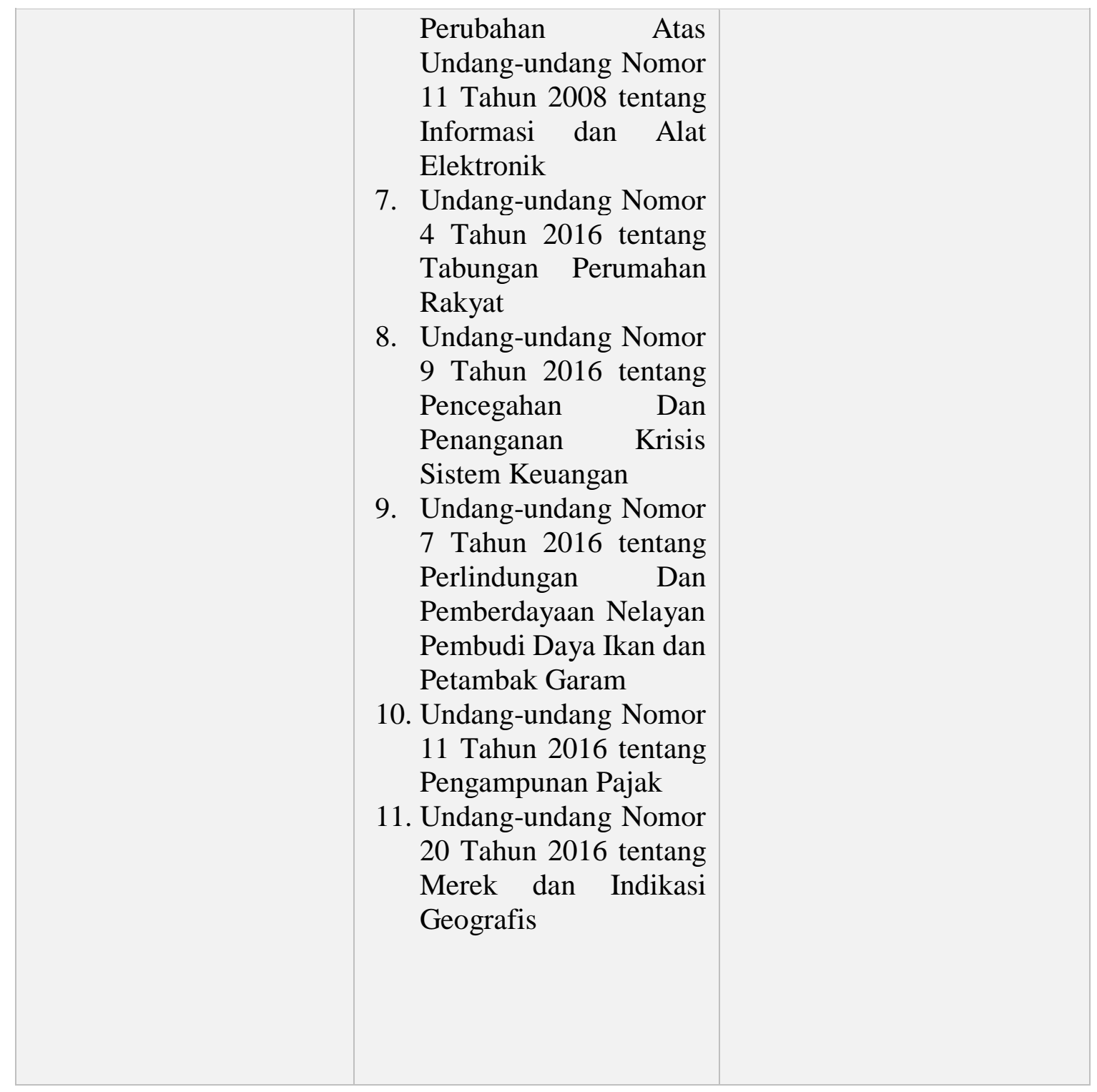

Berdasarkan tabel dapat dilihat adanya berdasar atas demokrasi ekonomi dengan peningkatan jumlah perundang-undangan prinsip keadilan, kebersamaan efisiensi yang berkaitan dengan Hak Ekososbud yang berkeadilan, berkelanjutan, berwawasan dibuat sejak tahun 2015, telah ada beberapa lingkungan, kemandirian, serta dengan upaya yang cukup signifikan untuk menjaga keseimbangan kemajuan dan memasukkan konsep SDGs didalam kesatuan ekonomi nasional, Dimana pembangunan nasional. Konsep ketentuan pasal ini dapat dikatakan sebagai pembangunan berkelanjutan sebagaimana asas dari demokrasi ekonomi yang diatur pendapat Jimly Ashiddiqie terdapat didalam pasal 33 UUD 1945 ayat (4) yang berbunyi Perekonomian nasional diselenggarakan 
dalam konstitusi RI. ${ }^{5}$

Pembangunan yang berkelanjutan adalah berkenaan dengan bagaimana memenuhi kebutuhan manusia sekarang tanpa perlu mengorbankan kebutuhan generasi mendatang; pembangunan yang menggabungkan antara green growth, yaitu nexus antara elemen (strands) ekonomi dan lingkungan dengan inclusive growth, yaitu nexus antara elemen sosial dan lingkungan. ${ }^{6}$ Pembangunan yang berkelanjutan merupakan suatu upaya untuk menghubungkan sejumlah titik isu global ketidakadilan, pertumbuhan penduduk, perubahan iklim, stress lingkungan, air, energi, dan keamanan pangan. Pengabaian terhadap satu titik akan menggagalkan pembuatan garis.

Pembangunan yang menekankan pada pemerataan lebih berdampak positif. Nilai positif ini setidaknya dapat dilihat dari dua aspek yaitu: Pertama, bahwa orientasi pembangunan yang menekankan pada pemerataan akan mengangkat kesejahteraan penduduk secara lebih luas. Dengan begitu, lebih banyak penduduk yang dapat menikmati hasil pembangunan. Kedua, secara timbal balik, karena semakin banyaknya penduduk yang kesejahteraannya meningkat, pada gilirannya akan lebih banyak lagi sumberdaya manusia yang dapat berpartisipasi dalam pembangunan. Dengan demikian keberlanjutan pembangunan menjadi lebih pasti. Sebaliknya orientasi pembangunan yang menekankan pada pertumbuhan akan lebih menghasilkan kesenjangan dalam masyarakat. ${ }^{7}$

Pembangunan berkelanjutan memiliki tiga tujuan utama, ${ }^{8}$ yaitu:

1. Economically viable: pembangunan ekonomi yang dinamis.

2. Socially-politically acceptable and culturally sensitive: pembangunan yang secara sosial politik dapat diterima serta peka terhadap aspek-aspek budaya.

3. Environmental friendly: ramah lingkungan.

Pembangunan berkelanjutan memiliki tiga pilar utama yang saling berkesinambungan, ${ }^{9}$ diantaranya:

a. Pertumbuhan ekonomi, yakni menjaga pertumbuhan ekonomi yang stabil dengan merestrukturisasi sistem produktif untuk menghemat sumber daya dan energi.

b. Keberlanjutan sosial, yakni menjamin keadilan sosial dalam distribusi kekayaan dan pelayanan sosial.

c. Keberlanjutan lingkungan, yakni dengan menjaga lingkungan tempat tinggal agar nyaman dan aman melalui zero emission.

\footnotetext{
Jimly Asshiddiqie, (2009), Green Constitution; Nuansa Hijau Undang -undang Dasar Republik Indonesia 1945, Jakarta, Rajawali Press, hlm. 133

6 Muhadjir Darwin, Dari MDGs KE SDGs, http://cpps.ugm.ac.id/dari-mdgs-ke-sdgs-oleh-muhadjir-darwin/

7 Urgensi Rencana Aksi Nasional Bisnis dan Hak Asasi Manusia http://elsam.or.id/2015/06/urgensipenyusunan-rencana-aksi-nasional-bisnis-dan-hak-asasi- manusia-di-indonesia

8 Patricia Rinwigati Waagstein. (2013), Business and Human Rights in ASEAN: A Baseline Study. HRRCA, hlm. 96

9 Konsep Pembangunan Berkelanjutan, http://kotahijau.id/knowledge/detail/pembangunan-berkelanjutan. Diakses pada tanggal 5 Juni 2019.
} 
Berdasarkan dari uraian diatas kiranya perlu dibahas beberapa hal diantaranya tentang permasalahan bagaimana konsep pembangunan berkelanjutan (suitainabel development) dalam Konstitusi Indonesia sertaa relasi konsep pembangunan berkerlanjutan terhadap pemenuhan HAM bagi rakyat Indonesia.

\section{PEMBAHASAN}

\section{Konsep Pembangunan Berkelanjutan} (Suistainabel Development) dalam

\section{Perundang-undangan Indonesia}

\section{Tujuan Pembangunan berkelanjutan}

Pembangunan berkelanjutan (Suistainable Development Goals) pada prinsipnya ditujukan dalam beberapa kerangka tujuan yang secara garis besar terdiri dari 17 tujuan yang di harapkan dapat tercapai diakhir pencanangan program ini secara global. Tujuan ini di antaranya:

1. Mengahiri kemiskinan dalam segala bentuk dan dimanapun

2. Mengakhiri kelaparan, mencapai ketahanan pangan,perbaikan nutrisi ,mempromosikan pertanian yang berkelanjutan.

3. Memastikan gaya hidup sehat dan mendukung kesejahteraan untuk semua usia.

4. Memastikan/menjamin pendidikan yang berkualitas dan inklusifserta kesempatan belajar seumur hidup bagi semua orang.

5. Mencapai kesetaraan gender dan kualitas hidup bagi perempuan dan anak perempuan

6. Memastikan ketersediaan dan manajemen yang berkelanjutan ketersediaan air dan sanitasi.
7. Memastikan akses yang terjangkau, terjaga/stabil, berkelanjutan,dan energi terbarukan bagi semua.

8. Mempromosikan keberlanjutan, inklusif dan pertumbuhan ekonomi yang berkelanjutan, pekerja produktif dan tetap, serta kesempatan kerja yang layak bagi semua.

9. Membangun infrastruktur yang kokoh, mempromosikan inklusifitas dan Industrialisasi berkelanjutan dan inovatif.

10. Mengurangi ketidaksetaraan/ kesenjangan diantara negara-negara.

11. Membuat kota dan tempat tinggal yang inklusif aman dan kokoh serta berkelanjutan

12. Memastikan pola konsumsi dan produksi yang berkelanjutan.

13. Mengambil langkah-langkah yang penting untuk melawan perubahan iklim dan dampaknya

14. Melakukan konservasi dan menjaga keberlanjutan penggunaan samudra, lautan dan sumberdaya kelautan untuk perkembangan keberlanjutan sumberdaya kelautan.

15. Melindungi, melakukan restorasi dan mempromosikan penggunaan beyang berkelanjutan ekosistem, manajemen pengelolaan hutan, mengatasi kekeringan dan penurunan kualitas tanahdan mempeertahankan keanekaragaman hayati.

16. Mempromosikan perdamaian dan masyarakat inklusif yang mendukung pembangunan yang berkelanjutan, akuntabilitas dan inklusif institusi dalam semua tingkatan.

17. Menekankan pentingnya implementasi dan kerjasama secara global dalam penerapan pembangunan berkelanjutan .

Indonesia sebagai salah satu Negara yang menandatangani komitmen pembangunan berkelanjutan ini secara otomatis terikat untuk mewujudkan komitmen ini secara optimal, optimalisasi tujuan ini dapat segara terwujud 
salah satunya dengan membuat suatu perangkat instrumen hukum yang dengan kerjasama yang berpotensi kompreshensif yang sanggup menjawab membebani masyarakat. Lebih lanjut tantangan-tantangan yang mungkin menjadi sebagaimana tertuang dalam tabel berikut penghambat pelaksanaan konsep ini, pembuktian komitmen ini secara nyata di jawab didalam berbagai produk perundangan yang di buat pasca ditandatangani komitmen ini pada tahun 2015, pada tahun 2015 pasca ditandatangani komitmen ini tercatat 1 Undang-Undang yang sudah memuat konsep pembangunan berkelanjutannya yakni UU no 2 Tahun 2015 yang menekankan pada rencana kerjasama internasional yang memerlukan

Tabel 2 Perkembangan konsep pembangunan berkelanjutan tahun 2015, 2016 dan 2017.

\begin{tabular}{|c|c|c|}
\hline No. & $\begin{array}{c}\text { Produk } \\
\text { Perundang- } \\
\text { undangan }\end{array}$ & $\begin{array}{c}\text { Perkembangan konsep } \\
\text { Suistainable Development }\end{array}$ \\
\hline \multicolumn{3}{|l|}{2015} \\
\hline 1. & \begin{tabular}{l}
\multicolumn{2}{l}{ Undang-undang } \\
Republik Indonesia \\
Nomor 2 Tahun \\
$2015 \quad$ tentang \\
Penetapan \\
Peraturan \\
Pemerintah \\
Pengganti Undang- \\
undang Nomor 2 \\
Tahun $\quad 2014$ \\
tentang Perubahan \\
Atas Undang- \\
Undang Nomor 23 \\
Tahun 2014 \\
tentang \\
Pemerintahan \\
Daerah menjadi \\
undang-undang
\end{tabular} & $\begin{array}{l}\text { Dalam ketentuan Pasal } 101 \text { huruf } \mathrm{f} \text {, g, h, dan I, DPRD } \\
\text { berwenang untuk memberikan pendapat dan pertimbangan } \\
\text { serta persetujuan terhadap rencana kerja sama internasional } \\
\text { yang dilakukan oleh pemerintah daerah provinsi dan rencana } \\
\text { kerja sama dengan Daerah lain atau dengan pihak ketiga yang } \\
\text { membebani masyarakat dan daerah provinsi dan meminta } \\
\text { laporan keterangan pertanggungjawaban gubernur dalam } \\
\text { penyelenggaraan Pemerintahan Daerah provinsi. }\end{array}$ \\
\hline
\end{tabular}




\begin{tabular}{|c|c|c|}
\hline \multicolumn{3}{|c|}{2016} \\
\hline 1. & $\begin{array}{l}\text { Undang-undang } \\
\text { Nomor } 13 \text { Tahun } \\
2016 \text { tentang Paten }\end{array}$ & $\begin{array}{l}\text { 1. Di dalam bagian umum UU ini dijelaskan konsep tentang } \\
\text { penguatan dukungan perkembangan teknologi terhadap } \\
\text { pembangunan nasional maka perkembangan teknologi } \\
\text { diarahkan pada peningkatan kualitas penguasaan dan } \\
\text { pemanfaatan teknologi dalam rangka mendukung } \\
\text { transformasi perekonomian menuju perekonomian yang } \\
\text { berbasis pada keunggulan kompetitif.dan dukungan ini } \\
\text { berlangsung secara konsisten dan berkelanjutan maka } \\
\text { sistem inovasi nasional perlu diperkuat melalui } \\
\text { pembentukan lembaga penelitian pemerintah atau swasta, } \\
\text { pemanfaatan sumber daya alam, pemberdayaan sumber } \\
\text { daya manusia dan sistem jaringan teknologi informasi, } \\
\text { pembudayaan penelitian, pengembangan dan penerapan } \\
\text { teknologi di bidang-bidang yang strategis dalam bentuk } \\
\text { publikasi ilmiah, layanan teknologi, maupun } \\
\text { wirausahawan teknologi. } \\
\text { 2. Urgensi perubahan Undang-Undang Paten antara lain } \rightarrow \\
\text { Invensi berupa penggunaan kedua dan selanjutnya (second } \\
\text { use dan second medical use) atas Paten yang sudah habis } \\
\text { masa pelindungan (public domain) tidak diperbolehkan. } \\
\text { 3. Paten dapat dialihkan dengan cara wakaf. } \\
\text { 4embuka kesempatan seluas-luasnya kepada industri } \\
\text { nasional untuk memanfaatkan Paten yang telah berakhir } \\
\text { masa pelindungannya secara optimal dan lepas dari } \\
\text { tuntutan hukum dan kewajiban membayar royalti. } \\
\text { Kerjasama Internasional Pemberian lisensi-wajib atas } \\
\text { permintaan Negara berkembang (developing country) atau } \\
\text { negara belum berkembang (least developed country) yang } \\
\text { membutuhkan produk farmasi yang diberi paten di } \\
\text { Indonesia untuk keperluan pengobatan penyakit yang } \\
\text { sifatnya endemi, dan produk farmasi tersebut } \\
\text { dimungkinkan diproduksi di Indonesia, untuk diekspor ke } \\
\text { negara tersebut. Sebaliknya pemberian lisensi-wajib untuk } \\
\text { mengimpor pengadaan produk farmasi yang diberi paten } \\
\text { di Indonesia namun belum mungkin diproduksi di } \\
\text { Indonesia untuk keperluan pengobatan penyakit yang } \\
\text { sifatnya endemik }\end{array}$ \\
\hline 2. & $\begin{array}{l}\text { Undang-undang } \\
\text { nomor 15 tahun } \\
2016 \text { Pengesahan } \\
\text { Maritime Labour } \\
\text { Convention, 2006 } \\
\text { (Konvensi } \\
\text { Ketenagakerjaan } \\
\text { Maritim, 2006) } \\
\text { Ketenagakerjaan } \\
\text { maritim 2006 }\end{array}$ & $\begin{array}{l}\text { Dimana didalam ketentuan-ketentuan didalam konvensi } \\
\text { memberikan kesetaraan akan perlimdumgan tenaga kerja baik } \\
\text { didarat maupun diatas kapal yang sebagaiman tercantum } \\
\text { dalam } 8 \text { (delapan) Konvensi Dasar ILO dan telah diakomodir } \\
\text { dalam ketentuan peraturan perundang-undangan nasional. } \\
\text { Hak-hak tersebut antara lain hak untuk bebas dari perbudakan, } \\
\text { hak untuk terhindar dari diskriminasi, hak untuk mendapatkan } \\
\text { upah yang sama untuk jenis pekerjaan yang sama nilainya, hak } \\
\text { untuk berunding bersama dan berserikat, hak untuk tidak } \\
\text { mempekerjakan anak dalam jenis pekerjaan terburuk. Selain } \\
\text { hak dasar, maka pelaut dan awak kapal juga berhak }\end{array}$ \\
\hline
\end{tabular}




\begin{tabular}{|c|c|c|}
\hline & & $\begin{array}{l}\text { mendapatkan perlindungan atas pekerjaan dan sosial, antara } \\
\text { lain hak untuk mendapatkan tempat kerja yang aman, hak } \\
\text { untuk mendapatkan perlindungan terhadap keselamatan dan } \\
\text { kesehatan kerja, hak untuk mendapatkan jaminan sosial, dan } \\
\text { hak untuk mendapatkan perawatan medik, fasilitas dan } \\
\text { akomodasi termasuk rekreasi. } \\
\text { Selain hak dasar tersebut awak kapal dan juga pelaut memiliki } \\
\text { mendapatkan berbagai perlindungan atas pekerjaan dan } \\
\text { kehidupan sosial, diantaranya hak untuk mendapatkan tempat } \\
\text { kerja yang aman, hak untuk mendapatkan perlindungan } \\
\text { terhadap keselamatan dan kesehatan kerja, hak untuk } \\
\text { mendapatkan jaminan sosial, dan hak untuk mendapatkan } \\
\text { perawatan medik, fasilitas dan akomodasi termasuk rekreasi. }\end{array}$ \\
\hline 3. & \begin{tabular}{lr}
\multicolumn{3}{l}{ Undang-undang } \\
Nomor 17 Tahun \\
$2016 \quad$ tentang \\
Penetapan \\
Peraturan \\
Pemerintah \\
Pengganti Undang- \\
undang Nomor 1 \\
Tahun & 2016 \\
tentang & Perubahan \\
Kedua r atas \\
Undang-undang \\
Nomor & 23 Tahun \\
2002 & tentang \\
Perlindungan Anak \\
menjadi undang- \\
undang
\end{tabular} & $\begin{array}{l}\text { Undang-undang secara subtantif menetapkan Peraturan } \\
\text { Pemerintah Pengganti Undang-undang Nomor } 1 \text { Tahun } 2016 \\
\text { tentang Perubahan Kedua Atas Undang-undang Nomor } 23 \\
\text { Tahun } 2002 \text { tentang Perlindungan Anak menjadi Undang- } \\
\text { undang dimana dalam satu pertimbangannya dicantumkan } \\
\text { tentang negara menjamin hak anak atas kelangsungan hidup, } \\
\text { tumbuh dan berkembang, serta perlindungan dari kekerasan } \\
\text { dan diskriminasi sebagaimana tercantum dalam Undang- } \\
\text { Undang Dasar Negara Republik Indonesia Tahun 1945, } \\
\text { bahwa kekerasan seksual terhadap anak dari tahun ke tahun } \\
\text { semakin meningkat dan mengancam peran strategis anak } \\
\text { sebagai generasi penerus masa depan bangsa dan negara, } \\
\text { sehingga perlu memperberat sanksi pidana dan memberikan } \\
\text { tindakan terhadap pelaku kekerasan seksual terhadap anak } \\
\text { dengan mengubah Undang-undang Nomor } 23 \text { Tahun } 2002 \\
\text { tentang Perlindungan Anak sebagaimana telah diubah dengan } \\
\text { Undang-Undang Nomor } 35 \text { Tahun } 2014 \text { tentang Perubahan } \\
\text { atas Undang-undang Nomor } 23 \text { Tahun 2002 tentang } \\
\text { Perlindungan Anak }\end{array}$ \\
\hline 4. & $\begin{array}{l}\text { Undang-undang } \\
\text { Nomor 16 Tahun } \\
2016 \text { tentang } \\
\text { Pengesahan Paris } \\
\text { Agreement To The } \\
\text { United Nations } \\
\text { Framework } \\
\text { Convention On } \\
\text { Climate Change } \\
\text { (persetujuan paris } \\
\text { atas konvensi } \\
\text { kerangka kerja } \\
\text { perserikatan } \\
\text { bangsa-bangsa }\end{array}$ & $\begin{array}{l}\text { Sebagai perwujudan semangat pengendalian perubahan iklim } \\
\text { merupakan amanat konstitusi bahwa setiap orang berhak } \\
\text { hidup sejahtera, lahir dan batin, bertempat tinggal, dan } \\
\text { mendapatkan lingkungan hidup yang baik dan sehat serta } \\
\text { berhak memperoleh pelayanan kesehatan. Negara } \\
\text { memberikan arah dan berkewajiban memastikan agar } \\
\text { pembangunan yang dibutuhkan untuk memenuhi } \\
\text { kesejahteraan rakyat tetap memperhatikan perlindungan aspek } \\
\text { lingkungan dan sosial. Dengan adanya kesadaran akan } \\
\text { ancaman dari dampak-dampak negatif perubahan iklim, } \\
\text { pengendalian dan penanganan perubahan iklim bukan } \\
\text { merupakan suatu beban bagi Negara, namun sudah saatnya } \\
\text { menjadi suatu kebutuhan. Dengan demikian komitmen Negara } \\
\text { dalam menangani perubahan iklim merupakan agenda } \\
\text { nasional persetujuan paris pada hakikatnya bersifat mengikat } \\
\text { secara hukum dan diterapkan semua negara (legally binding }\end{array}$ \\
\hline
\end{tabular}




\begin{tabular}{|c|c|c|}
\hline & $\begin{array}{l}\text { mengenai } \\
\text { perubahan iklim) }\end{array}$ & 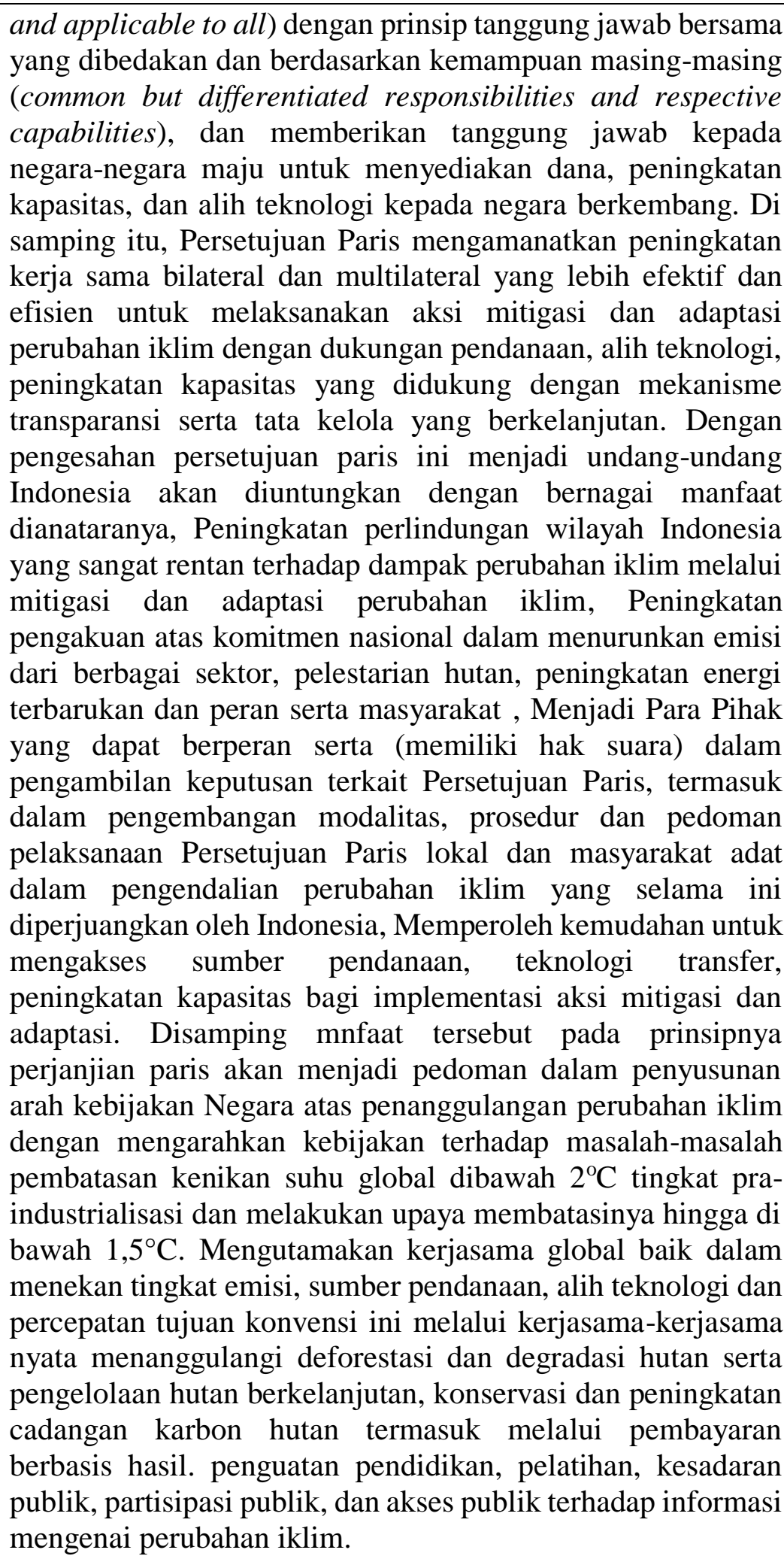 \\
\hline 5. & $\begin{array}{l}\text { Undang-undang } \\
\text { Nomor } 8 \text { Tahun } \\
2016 \text { tentang } \\
\text { Penyandang } \\
\text { Disabilitas }\end{array}$ & $\begin{array}{l}\text { Undang-undang ini merupakan perubahan dari Undang- } \\
\text { undang Nomor } 4 \text { Tahun } 1997 \text { tentang Penyandang Cacat, } \\
\text { sudah tidak sesuai lagi dengan paradigma kebutuhan } \\
\text { penyandang disabilitas sehingga perlu diganti dengan undang- } \\
\text { undang yang baru yang dianggap sudah tidak relevan dengan } \\
\text { penyandang disabilitas di Indonesia hidup dalam kondisi }\end{array}$ \\
\hline
\end{tabular}




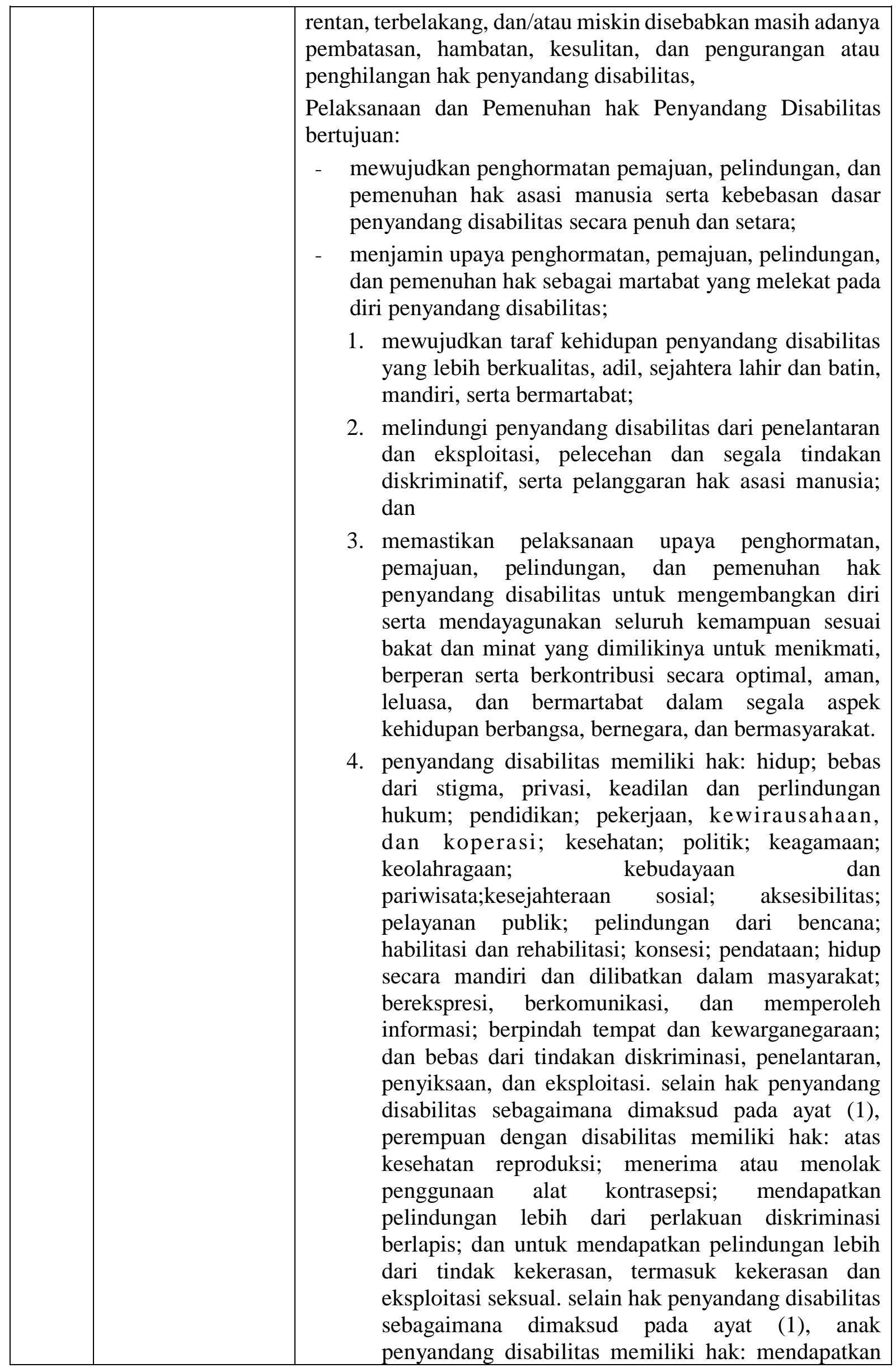




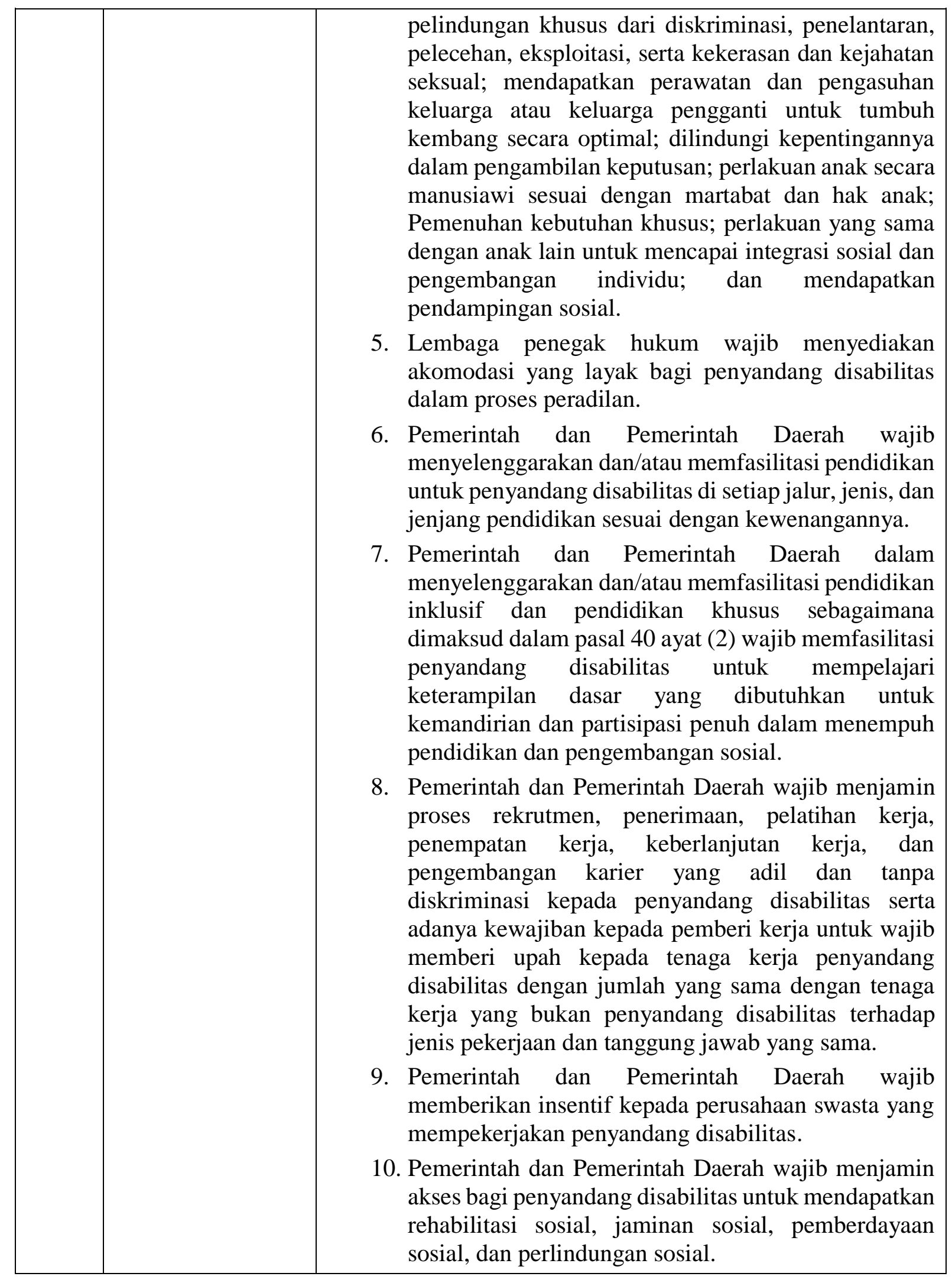




\begin{tabular}{|c|c|c|}
\hline 6. & $\begin{array}{l}\text { Undang-Undang } \\
\text { Nomor 19 Tahun } \\
2016 \text { tentang } \\
\text { Perubahan Atas } \\
\text { Undang-undang } \\
\text { Nomor 11 Tahun } \\
2008 \text { tentang } \\
\text { Informasi dan Alat } \\
\text { Elektronik }\end{array}$ & $\begin{array}{l}\text { Di dalam UU perubahan ini termuat tentang laranngan } \\
\text { intersepsi ataupun penyadapan }\end{array}$ \\
\hline 7. & \begin{tabular}{l}
\multicolumn{3}{l}{ Undang-Undang } \\
Nomor 4 tahun \\
$2016 \quad$ tentang \\
Tabungan \\
Perumahan Rakyat
\end{tabular} & $\begin{array}{l}\text { Memcermati kondisi sebelum lahirnya Undang-undang ini } \\
\text { dimana peraturan perundang-undangan di bidang perumahan } \\
\text { dan sistem jaminan sosial belum mengatur secara } \\
\text { komprehensif mengenai penyelenggaraan tabungan } \\
\text { perumahan sehingga diperlukan pengaturan yang lebih } \\
\text { lengkap, terperinci, dan menyeluruh dan sebagai upaya } \\
\text { pemenuhan kebutuhan akan tempat tinggal yang layak masih } \\
\text { dihadapkan pada persolan belum tersedianya dana murah } \\
\text { jangka panjang untuk menunjang pembiayaan perumahan } \\
\text { rakyat;sehingga pemerintah merasa perlu untuk menghimpun } \\
\text { dan menyediakan dana murah jangka panjang sebagai } \\
\text { penunjang pembiayaan perumahan, karenanya negara perlu } \\
\text { menyelenggarakan sistem tabungan perumahan; } \\
\text { Dengan tujuan Pembiayaan perumahan bagi Peserta } \\
\text { sebagaimana dimaksud dalam Pasal } 24 \text { UU ini meliputi } \\
\text { pembiayaan: a. pemilikan rumah; b. pembangunan rumah; } \\
\text { atau c. perbaikan rumah. Dengan ketentuan pembiayaan bagi } \\
\text { peserta yang dimaksud dalam UU ini a. merupakan rumah } \\
\text { pertamadan hanya diberikan satukali dan memiliki nilai } \\
\text { besaran tertentu untuk tiap-tiap pembiayaan perumahan. } \\
\text { Dengan sasaaran peserta pembiayaan rumah yang di tujukan } \\
\text { kepada mereka yang memiliki masa kepesertaan paling } \\
\text { singkat } 12 \text { (dua belas) bulan, termasuk golongan masyarakat } \\
\text { berpenghasilan rendah, belum memiliki rumah; dan/atau, } \\
\text { menggunakannya untuk pembiayaan kepemilikan rumah, } \\
\text { pembangunan rumah, atau perbaikan rumah pertama. }\end{array}$ \\
\hline 8. & $\begin{array}{l}\text { Undang-Undang } \\
\text { Nomor } 7 \text { Tahun } \\
2016 \text { tentang } \\
\text { Perlindungan dan } \\
\text { Pemberdayaan } \\
\text { Nelayan Pembudi } \\
\text { Daya Ikan dan } \\
\text { Petambak Garam }\end{array}$ & $\begin{array}{l}\text { peraturan perundang-undangan yang mengatur mengenai } \\
\text { perlindungan dan pemberdayaan nelayan, pembudi daya ikan, } \\
\text { dan petambak garam sebelum adanya undang-undang ini } \\
\text { daingggap belum komprehensif sebagai sarana pendukung } \\
\text { perwujudan tujuan negara dalam usaha menyejahterakan } \\
\text { rakyat, termasuk nelayan, pembudi daya ikan, dan petambak } \\
\text { garam, nelayan, pembudi daya ikan, dan petambak garam } \\
\text { sangat tergantung pada sumber daya ikan, kondisi } \\
\text { lingkungan, sarana dan prasarana, kepastian usaha, akses } \\
\text { permodalan, ilmu pengetahuan, teknologi, dan informasi } \\
\text { sehingga membutuhkan perlindungan dan pemberdayaan; } \\
\text { negara menyelenggarakan perlindungan dan pemberdayaan } \\
\text { nelayan, pembudi daya ikan, dan petambak garam secara } \\
\text { terencana, terarah, dan berkelanjutan; yang bertujuan untuk }\end{array}$ \\
\hline
\end{tabular}




\begin{tabular}{|c|c|c|}
\hline & & $\begin{array}{l}\text { menyediakan saranadan prasarana yang dibutuhkan dalam } \\
\text { mengembangkan usaha; memberikan kepastian usaha yang } \\
\text { berkelanjutan;meningkatkan kemampuan dan kapasitas } \\
\text { nelayan, pembudi daya ikan, dan petambak garam; } \\
\text { menguatkan kelembagaan dalam mengelola sumber daya ikan } \\
\text { dan sumber daya kelautan serta dalam menjalankan usaha } \\
\text { yang mandiri, produktif, maju, modern, dan berkelanjutan; } \\
\text { dan mengembangkan prinsip kelestarian lingkungan; } \\
\text { menumbuhkembangkan sistem dan kelembagaan pembiayaan } \\
\text { yang melayani kepentingan usaha; melindungi dari risiko } \\
\text { bencana alam, perubahan iklim, serta pencemaran; dan } \\
\text { memberikan jaminan keamanan dan keselamatan serta } \\
\text { bantuan hukum. }\end{array}$ \\
\hline 9. & $\begin{array}{l}\text { Undang-Undang } \\
\text { Nomor 20 Tahun } \\
2016 \text { tentang } \\
\text { Merek dan Indikasi } \\
\text { Geografis }\end{array}$ & $\begin{array}{l}\text { Menggantikan Undang-Undang Nomor } 15 \text { Tahun } 2001 \\
\text { tentang Merek yang masih terdapat kekurangan serta tidak } \\
\text { menampung perkembangan kebutuhan masyarakat di bidang } \\
\text { Merek dan Indikasi Geografis dan dianggap belum } \\
\text { memberikan perlindungan yang cukup terhadap potensi } \\
\text { ekonomi lokal dan nasional sehingga di perlukan instrument } \\
\text { hukum baru yang dapat mengakomodir kebutuhan tersebut } \\
\text { sehingga dapat lebih meningkatkan pelayanan dan } \\
\text { memberikan kepastian hukum bagi dunia industri, } \\
\text { perdagangan, dan investasi dalam menghadapi perkembangan } \\
\text { perekonomian lokal, nasional, regional, dan internasional } \\
\text { serta perkembangan teknologi informasi dan komunikasi, } \\
\text { perlu didukung oleh suatu peraturan perundang-undangan di } \\
\text { bidang merek dan indikasi geografis yang lebih memadai }\end{array}$ \\
\hline \multicolumn{3}{|c|}{2017} \\
\hline 1. & \begin{tabular}{l}
\multicolumn{2}{l}{ Undang-undang } \\
Nomor 5 Tahun \\
2017 tentang \\
Pemajuan \\
Kebudayaan
\end{tabular} & $\begin{array}{l}\text { bahwa selama ini belum terdapat peraturan perundang- } \\
\text { undangan yang memadai sebagai pedoman dalam Pemajuan } \\
\text { Kebudayaan Nasional Indonesia secara menyeluruh dan } \\
\text { terpadu; sehingga diperlukan instrument hukum khusus yang } \\
\text { diharapkan mampu mendorong percepatan kemajuan } \\
\text { Kebudayaan Nasional Indonesia, yang dibarengi dengan } \\
\text { langkah strategis berupa upaya Pemajuan Kebudayaan } \\
\text { melalui Pelindungan, Pengembangan, Pemanfaatan, dan } \\
\text { Pembinaan guna mewujudkan masyarakat Indonesia yang } \\
\text { berdaulat secara politik, berdikari secara ekonomi, dan } \\
\text { berkepribadian dalam Kebudayaan; dengan mendorong } \\
\text { kembali pengembangan budaya terutama budaya yang } \\
\text { menjadi Objek Pemajuan Kebudayaan meliputi: a. Tradisi } \\
\text { lisan; b. Manuskrip; c. Adat istiadat; d. Ritus; e. Pengetahuan } \\
\text { tradisional; f. Teknologi tradisional; g. Seni; h. Bahasa; i. } \\
\text { Permainan rakyat; dan j. Olahraga tradisional. }\end{array}$ \\
\hline 2. & $\begin{array}{l}\text { Undang-undang } \\
\text { Nomor } 11 \text { Tahun } \\
2017 \quad \text { tentang } \\
\end{array}$ & $\begin{array}{l}\text { Pengesahan konvensi Minamata Convention on Mercury } \\
\text { (Konvensi Minamata mengenai Merkuri), bertujuan } \\
\text { melindungi kesehatan manusia dan keselamatan lingkungan }\end{array}$ \\
\hline
\end{tabular}




\begin{tabular}{|c|c|c|}
\hline & $\begin{array}{l}\text { Pengesahan } \\
\text { Minamata } \\
\text { Convention On } \\
\text { Mercury }\end{array}$ & $\begin{array}{l}\text { hidup dari emisi dan pelepasan merkuri serta senyawa } \\
\text { merkuri yang diakibatkan oleh aktivitas manusia hal ini } \\
\text { dikarenakan pemanfaatan merkuri sebagai bagian aktivitas } \\
\text { manusia berpotensi memberikan dampak serius terhadap } \\
\text { kesehatan manusia dan lingkungan hidup sehingga diperlukan } \\
\text { kerja sama antarnegara maupun global secara lebih efektif; }\end{array}$ \\
\hline 3. & \begin{tabular}{lrr}
\multicolumn{2}{l}{ Undang-undang } \\
Nomor 6 & Tahun \\
2017 & tentang \\
Arsitek &
\end{tabular} & $\begin{array}{l}\text { Tujuan pengaturan arsitek sebagaimana termuat dalam Pasal } \\
3 \text { UU ini diarahkan untuk: a. memberikan landasan dan } \\
\text { kepastian hukum bagi Arsitek; memberikan pelindungan } \\
\text { kepada Pengguna Jasa Arsitek dan masyarakat dalam Praktik } \\
\text { Arsitek; memberikan arah pertumbuhan dan perkembangan } \\
\text { profesi Arsitek yang berdaya saing tinggi serta memiliki } \\
\text { keahlian dan hasil pekerjaan yang berkualitas; mendorong } \\
\text { peningkatan kontribusi Arsitek dalam pembangunan nasional } \\
\text { melalui penguasaan dan pemajuan ilmu pengetahuan, } \\
\text { teknologi, dan seni; dan meningkatkan peran Arsitek dalam } \\
\text { mewujudkan pelaksanaan pembangunan yang berwawasan } \\
\text { lingkungan serta menjaga dan mengembangkan budaya dan } \\
\text { peradaban Indonesia. Tujuan ini diharapkan akan dapat } \\
\text { terwujud sebagai wujud konkret dengan arah suistainable } \\
\text { development yang berelasi erat dengan asas UU ini yakni } \\
\text { profesionalitas; integritas; c. etika; keadilan; keselarasan; } \\
\text { kemanfaatan; keamanan dan keselamatan; kelestarian; dan } \\
\text { keberlanjutan. }\end{array}$ \\
\hline 4. & \begin{tabular}{l}
\multicolumn{3}{l}{ Undang-undang } \\
Nomor 7 Tahun \\
$2017 \quad$ tentang \\
Pemilihan Umum
\end{tabular} & $\begin{array}{l}\text { Undang-undang ini merupakan produk penyatuan berbagai } \\
\text { undang-undang dalam rangka menyambut pemilu serentak } \\
\text { yang akan di selenggarakan pada tahun } 2019 \text { hal ini } \\
\text { diperlukan diperlukan sebagai sarana pengaturan pemilihan } \\
\text { umum dalam usaha perwujudan sistem ketatanegaraan yang } \\
\text { demokratis dan berintegritas demi menjamin konsistensi dan } \\
\text { kepastian hukum serta pemilihan umum yang efektif dan } \\
\text { efisien dimana dengan kehadiran Undang-undang ini } \\
\text { diharapkan dapat mengawal tradisi demokratis pemilihan } \\
\text { umum wajib menjamin sarana tersalurkannya suara rakyat } \\
\text { secara langsung, umum, bebas, rahasia, jujur, dan adil }\end{array}$ \\
\hline
\end{tabular}

Konsep Pembangunan Berkelanjutan

Dalam Rangka Pemenuhan Hak Ekonomi

Sosial dan Budaya Bagi Warga Negara

Indonesia

Konsep pembangunan berkelanjutan (sustainable development) didefinisikan sebagai develpoment which meets the needs of the present without compromising the ability of future generations to meet their own needs. Istilah ini pertama kali dipopulerkan dalam Our Common Future, laporan Komisi Dunia untuk Lingkungan Hidup dan Pembangunan the world Commission on Environment and Development (WCED yang dipublikasikan) pada tahun 1987 sejak awal konsep pembangunan berkelanjutan mempunyai 
banyak defenisi. Meski demikian, beberapa hal prinsip ditekankan dalam konsep ini yakni Pertama, komitmen pada keadilan dan fairness, dimana prioritas pembangunan global seharusnya diprioritaskan kepada masyarakat dunia yang paling miskin dan semua keputusan pembangunan global seharusnya mempertimbangkan hak-hak generasi yang akan datang. Kedua, sebagai suatu konsep Pembangunan berkelanjutan sustainable development merupakan suatu pandangan bersifat jangka panjang yang menekankankan prinsip-prinsip precautionary, yaitu, dimana ada ancaman serius atau sesuatu yang tidak, bisa dicegah, kekurangan kepastian pengetahuan secara penuh seyogyanya tidak digunakan sebagai alasan untuk menunda ukuran-ukuran biaya efektif (cost-effective measures) guna mencegah degradasi lingkunganll. Ketiga, pembangunan berkelanjutan mengintegrasikan, dan memahami, sekaligus bertindak dalam relasi yang kompleks antara lingkungan, ekonomi, dan masyarakat, pembangunan ekonomi, dan keadilan sosial. ${ }^{10}$

Konsep pembangunan berkelanjutan menjadi satu langkah nyata pemenuhan hak asasi manusia secara global terutama hak asasi manuasia yang muncul sebagai bagian dari hak generasi kedua yang fokus terhadap hakhak Ekonomi, sosial dan budaya, sebagaimana isi dari konvenan internasional tentang hak ekososbud yang memuat tentang uraian kebebasan atas hak, pemantauan dan pelaksanaan hak-hak mengingat bahwa didalam masyarakat global terdapat perbedaan sistem kesajahteraan, ekonomi dan sosial sehingga berpengaruh terhadap tingkat pendapatan yang berbeda. Namun harus dipastikan bahwa setiap orang berapapun pendapatannya harus dapat mengakses hakhak ekonomi, sosial dan budaya terutama berkaitan dengan hak pendididkan, hak pekerja, hak standart hidup yang layak dengan kemudahan akses terhadap makanan dan air bersih serta hak atas perumahan yang layak. ${ }^{11}$

Perumusan hak-hak tersebut dalam konsep pembangunan berkelanjutan secara nyata telah tertuang dalam tiga pilar utama Pembangunan berkelanjutan yang saling berkesinambungan pilar dalam Pertumbuhan ekonomi, yakni menjaga pertumbuhan ekonomi yang stabil dengan merestrukturisasi sistem produktif untuk menghemat sumber daya dan energi. Keberlanjutan sosial, yakni menjamin keadilan sosial dalam distribusi kekayaan dan pelayanan sosial. Keberlanjutan lingkungan, yakni dengan menjaga lingkungan tempat tinggal agar nyaman dan aman melalui zero emission.

Dalam kerangka nasional perwujudan tiga pilar ini diselaraskan juga dengan tujuan

\footnotetext{
10 Muhammad Fardan Ngoyo, Mengawal Sustainable Development Goals (SDGs); Meluruskan Orientasi Pembangunan yang Berkeadilan, Sosioreligius, Volume I, Nomor 1 Juni 2015, hlm 81.

11 Eko Riyadi, (2018), Hak Asasi Manusia, Jakarta; Rajawali Pers, hlm, 114
} 
konsep pembangunan berkelanjutan (sustainable development goals) sebagaimana berikut:

1. Mengahiri kemiskinan dalam segala bentuk dan dimanapun

2. Mengakhiri kelaparan, mencapai ketahanan pangan, perbaikan nutrisi, mempromosikan pertanian yang berkelanjutan.

3. Memastiakn gaya hidup sehat dan mendukung kesejahteraan untuk semua usia.

4. Memastikan/ menjamin pendidikan yang berkualitas dan inklusifserta kesempatan belajar seumur hidup bagi semua orang.

5. Mencapai kesetaraan gender dan kualitas hidup bagi perempuan dan anak perempuan

6. Memastikan ketersediaan dan manajemen yang berkelanjutan ketersediaan air dan sanitasi.

7. Memastikan akses yang terjangkau, terjaga/stabil, berkelanjutan, dan energi terbarukan bagi semua.

8. Mempromosikan keberlanjutan, inklusif dan pertumbuhan ekonomi yang berkelanjutan, pekerja produktif dan tetap, serta kesempatan kerja yang layak bagi semua.

9. Membangun infrastruktur yang kokoh, mempromosikan inklusifitas dan Industrialisasi berkelanjutan dan inovatif.

10. Mengurangi ketidaksetaraan/ kesenjangan diantara negara-negara.

11. Membuat kota dan temapt tinggal yang inklusif aman dan kokoh serta berkelanjutan

12. Memastikan pola konsumsi dan produksi yang berkelanjutan.

13. Mengambil langkah-langkah yang penting untuk melawan perubahan iklim dan dampaknya

14. Melakukan konservasi dan menjaga keberlanjutan penggunaan samudra, lautan dan sumberdaya kelautan untuk perkembangan keberlanjutan sumberdaya kelautan.

15. Melindungi, melakukan restorasi dan mempromosikan penggunaan beyang berkelanjutan ekosistem, manajemen pengelolaan hutan, mengatasi kekeringan dan penurunan kualitas tanahdan mempeertahankan keanekaragaman hayati.

16. Mempromosikan perdamaian dan masyarakat inklusif yang mendukung pembangunan yang berkelanjutan, akuntabilitas dan inklusif institusi dalam semua tingkatan.

17. Menekankan pentingnya implementasi dan kerjasama secara global dalam penerapan pembangunan berkelanjutan.

Dimana konsep ini kemudian di tindaklanjuti secara nasional yang dituangkan dalam perundang-undangan yang dibuat pasca penandatanganan komitmen ini oleh Indonesia di tahun 2015. Pasca penandatanganan ini tercatat ada 14 Undangundang didalamnya mengatur secara lebih detail penerapan tujuan pembangunan 
berkelanjutan baik didalam pertimbangan, maupun didalam batang tubuh Undangundang baru sebagaimana dalam tabel diatas.

\section{KESIMPULAN}

Dengan banyakknya perundangan yang terilhami dan memuat tentang rencana dan tujuan komitmen pembangunan global yang telah di buat secara nasional secara nyata telah menunjuukan adanya komitmen kuat dari pemerintah untuk melaksanakan dan mengambil bagian dari perwujudan konsep pembangunan berkelanjutan secara global. Dalam kurun waktu 3 tahun tercatat ada 14 Undang-Undang yang terkait konsep Pembangunan berkelanjutan dapat dijadikan ukuran tingginya komitmen Indonesia terhadap pembangunan berkelanjutan global mengingat Undang-undang yang dihasilkan dalam periode setelah penendatanganan Komitmen ini berjumlah sekitar 25 undangundang di berbagai bidang.

\section{SARAN}

Sebagai Negara yang telah mengikatkan diri dengan komitmen global dalam penerapan pembangunan secara global indonesi perlu lebih jauh mengatur tentang bagaimana konsep kerjasama dan fokus pengembannga terutama upaya keberlanjutan terhadap sumberdaya hayati serta pengembangan sumberdaya manusia yang lebih konkrit

\section{DAFTAR PUSTAKA}

\section{Buku}

Mutaqien, A, (ed), (2013), Uji Publik Terhadap Rancangan Revisi Permentan 26/2007 Tentang Pedoman Izin Usaha Perkebunan, Jakarta: ELSAM.

(20120, Undangundang Perkebunan, Wajah Baru Agrarische Wet: Dasar Alasan Pembatalan Pasal- Pasal Kriminalisasi oleh Mahkamah Konstitusi, Jakarta; Sawit Watch dan Pilnet.

Human Rights Resource Centre, 2013, Bussiness and Human Rights in ASEAN; A Baseline Study, Jakarta: Human Rights Resource Centre.

Putra, I,B, (2003), Hukum Lingkungan Internasional; Perspektif Bisnis Internasional: Bandung Refika Aditama

Asshiddiqie, J, (2010), Green Constitution; Nuansa Hijau Undang- Undang Dasar Republik Indonesia tahun 1945. Jakarta:Rajawali Press

Kusumaatmadja, M, dan Sidharta, A, B, (2000),Pengantar Ilmu Hukum,Suatu Pengenalan Pertama Ruang Lingkup Berlakunya Ilmu Hukum,Buku I, Bandung: Alumni.

Erwin, M, (2008), Hukum Lingkungan; Dalam Sistem Kebijaksanaan Pembangunan Lingkungan Hidup, Bandung: Refika Aditama.

Topan, M, (2009), Kejahatan Korporasi di Bidang Lingkungan Hidup (Perspektif Viktimologi dalam Pembaharuan Hukum Pidana di Indonesia ), Bandung: Nusamedia.

Husein, M, Z, (2014), Regulasi Bisnis di Sektor Perkebunan dan Hak Asasi Manusia, Jakarta: ELSAM. 
Muladi dan Muladi, D, (2010), Pertanggung jawaban Pidana Korporasi, Jakarta: Kencana.

Setiyono, (2009), Kejahatan Korporasi ( Analisa Victimologis dan Pertanggungjawaban Korporasi, Dalam Hukum Pidana Indonesia), Malang: Bayu Media.

\section{Jurnal}

Ngoyo, M, F, (2015. Juni, 1) Mengawal Sustainable Development Goals (SDGs); Meluruskan Orientasi Pembangunan yang Berkeadilan, Sosioreligius Volume I No.1. 2015. 